\title{
Subject
}

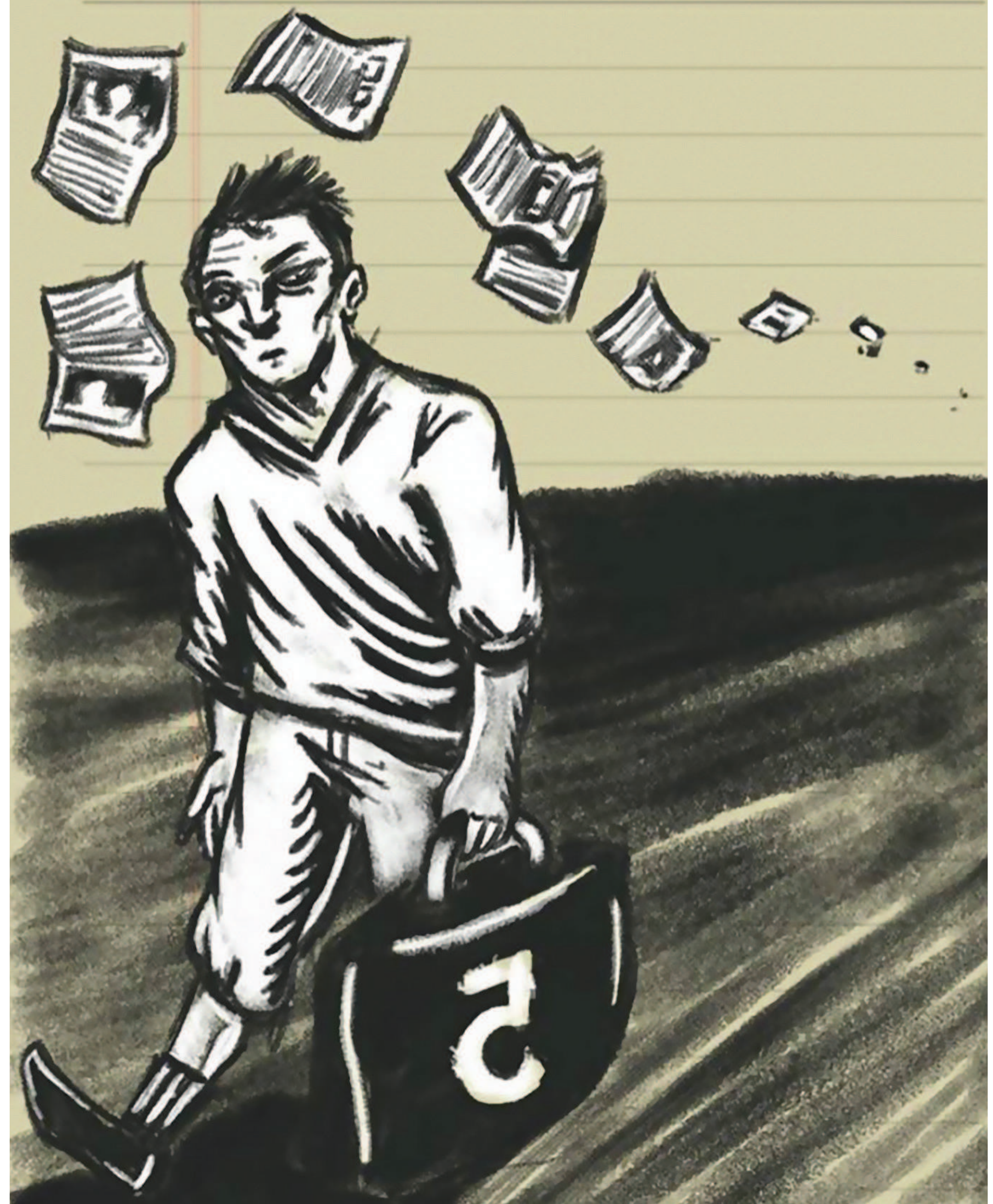



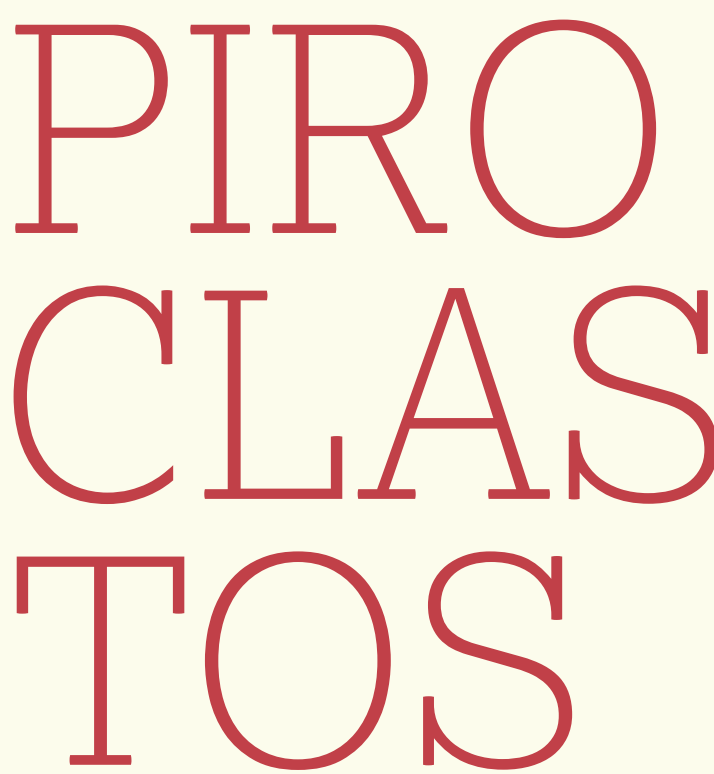

Do grego piro + klastós, -é, -ón.

Fragmentos de fogo expelidos durante a erupção e que solidificam. 


\section{INÉDITOS E 1 DE CAMISA QUAL}

- CÂNDIDO ROLIM

\section{ALAN BAHIA, VOLANTE}

Na cabeça álacre de Alan

Bahia um talhe ensopado de sangue

a céu aberto

a carne de Alan

Bahia toureada na Arena da

Baixada surdo remeiro ainda

nos ferros

a cabeça Niké

lada decotada a sabre

persigno de Gottfried

orixá

a cabeça de Alan

Bahia sangra sobre os

remendos negros da bola

na argila

a cabeça cápsula do negro

Alan Bahia ensaia um voo

suturado - jogo sufocado

desde o início 


\section{AMANTE À MODA ANTÍFONA}

queria um perfume de longe

deu-lhe um atavio encarnado

pediu um ônix

trouxe-lhe as minúcias de um salmo

esperava um paiol

entregou-lhe um feixe de blandícia

sugeriu um cruzeiro

deu-lhe o eclipse

pediu um carro zero

deu-lhe uma safra inteira de sigilo 


\section{UM DECALQUE}

A meiguice desse São Sebastião flechado

vê algo acima do dolor acinte de quem

esquece a vida que leva e o gesto pelo contrário

olhos elevados numa calma poderosa

feridas sangram a meio pau dardos

pendem das costelas - pingentes:

uma crueldade impotente só foi até

ali - na mais tenra margem - nada parece

desalinhar a obsessão nada de queixume

pessoas em volta nem amparo visível

a dor é dissolvida nesse elemento axial: o corpo

seminu regendo o próprio martírio sem

o rancor que irriga os desastres despertando

menos devoção que desejo 
454 MAGMA_PIROCLASTOS

\section{MÃE}

estranho só agora

posso medir esse tempo em

que vivemos chamando um

pelo outro - aquela perenidade

menor a cada dia 


\section{PLANO}

Espio vagarosamente

a cidade e fico

imaginando quanta

residência fixa. 


\section{ELE ME APONTA UMA JÓIA}

poeta de uníssona beleza

não vá você querer

que eu tenha

idêntico impacto

nem tudo parece ser

merecedor de afinco

(entendo o preito àqueloutro

o da predileção: faz

um uso novo da metáfora)

mas não vejo assim

motivo para deitar aos pés

elogio à

altura do homenageado

há tanto para ver no visto

que desconfio já

ser passado esse indício

de rareza

CÂNDIDO ROLIM (Várzea Alegre-CE, 1965). Formado em Direito pela Pontifícia Universidade Católica de Porto Alegre-RS. Publicou: Arauto (Edições Dubolso, Sabará/MG, 1988), Exemplos Alados (Letra e Música, Fortaleza/CE, 1997), Pedra Habitada (AGE, Porto Alegre, 2002, traduzido ao espanhol pela Amotape, Lima, Peru, 2014), Camisa qual (Éblis, Porto Alegre, 2010). Reside atualmente em Fortaleza. 